\title{
Dealing with Iguanas in the South Florida Landscape ${ }^{1}$
}

W. H. Kern, Jr. ${ }^{2}$

\section{Introduction}

Due to Florida's prominence in the exotic pet trade, iguanas imported as pets have escaped or been released, and are now established in South Florida. This has created unique problems for Florida's homeowners and businesses. South and Central Florida's subtropical climate allows these large herbivorous (plant-eating) lizards to survive, reproduce, and become part of the Florida environment. Three large members of the iguana family (Iguanidae) have become established in south Florida. These are the common green iguana (Iguana iguana), the Mexican spiny-tailed iguanas

(Ctenosaura pectinata) and black spiny-tailed iguana (C. similis). Large male spiny-tailed iguanas are often misidentified as alligators by startled homeowners because of reduced dorsal spines and dark color. There are many other large lizards established in Florida that some people misidentify as iguanas. The brown basilisk (Basiliscus vittatus) is a large (up to 2 feet) lizard that is often mistaken for an iguana and occurs in the same areas as introduced iguanas. Knight anoles (Anolis equestris) commonly reach between 12-18 inches. Jamaican giant anole (Anolis garmani) males can reach 12 inches. People in South Florida often call these large green anoles "iguanas" or "iguanitos." Occasionally escaped pets that have not established breeding populations are seen by surprised neighbors. These include large lizards like many of the monitor lizards (Varanus $s p$.).

\section{Identification}

See Figures 1 through 9.

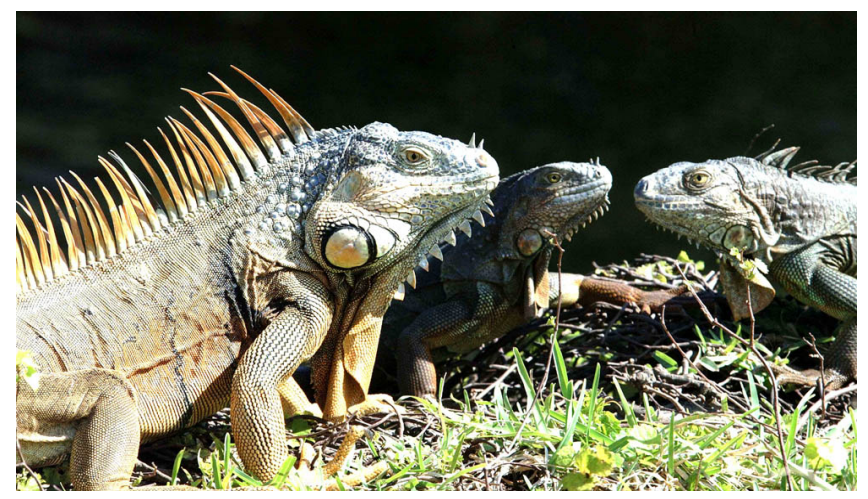

Figure 1. Adult green iguanas (Iguana iguana) with male on the left. Credits: Thomas Wright, University of Florida

\section{Habits}

Adult iguanas are herbivores' feeding on foliage, flowers, and fruit. They will occasionally eat animal material such as insects, lizards and other small animals, nestling birds and eggs. Juveniles eat more animal material, especially insects, and hatchling

1. This document is Fact Sheet ENY-714, a series of the Entomology and Nematology Department, Florida Cooperative Extension Service, Institute of Food and Agricultural Sciences, University of Florida. Publication date: August 2004. Please visit the EDIS Website at http://edis.ifas.ufl.edu.

2. W. H. Kern, Jr., assistant professor, Entomology and Nematology Department, Ft. Lauderdale Research and Education Center, Cooperative Extension Service, Institute of Food and Agricultural Sciences, University of Florida, Ft. Lauderdale, FL.

The Institute of Food and Agricultural Sciences is an equal opportunity/affirmative action employer authorized to provide research, educational information and other services only to individuals and institutions that function without regard to race, color, sex, age, handicap, or national origin. For information on obtaining other extension publications, contact your county Cooperative Extension Service office. Florida Cooperative Extension Service/Institute of Food and Agricultural Sciences/University of Florida/Christine Taylor Waddill, Dean. 


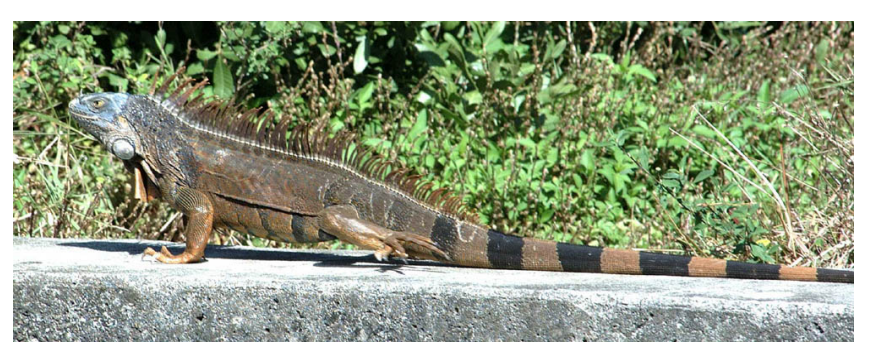

Figure 2. Adult green iguana (Iguana iguana) on a seawall. Credits: Thomas Wright, University of Florida

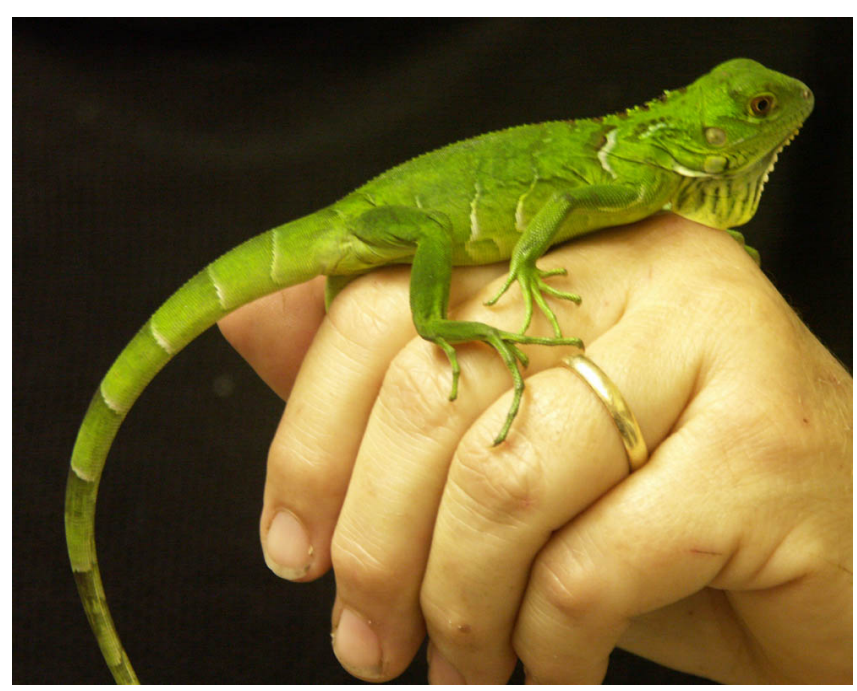

Figure 3. Juvenile green iguana. This hatchling is an attractive size for a pet or to sell to a pet store. Credits: W. H. Kern, Jr., University of Florida, Ft. Lauderdale

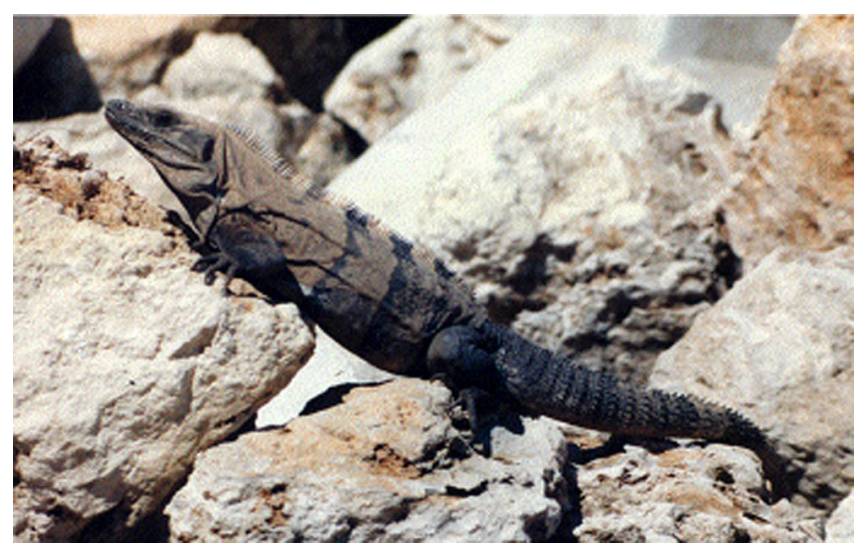

Figure 4. Adult male black spiny-tailed iguana (Ctenosaura similis). Credits: W. H. Kern, Jr., University of Florida, Ft. Lauderdale

green iguanas eat the droppings of adult iguanas to acquire the gut bacteria that help them digest plant material. Males are territorial against other males, but are not territorial against females and juveniles. These large lizards like to bask in open areas; sidewalks, docks, seawalls, landscape timbers, or open mowed areas. If frightened, they dive into water (green iguanas and basilisks) or retreat into their burrows

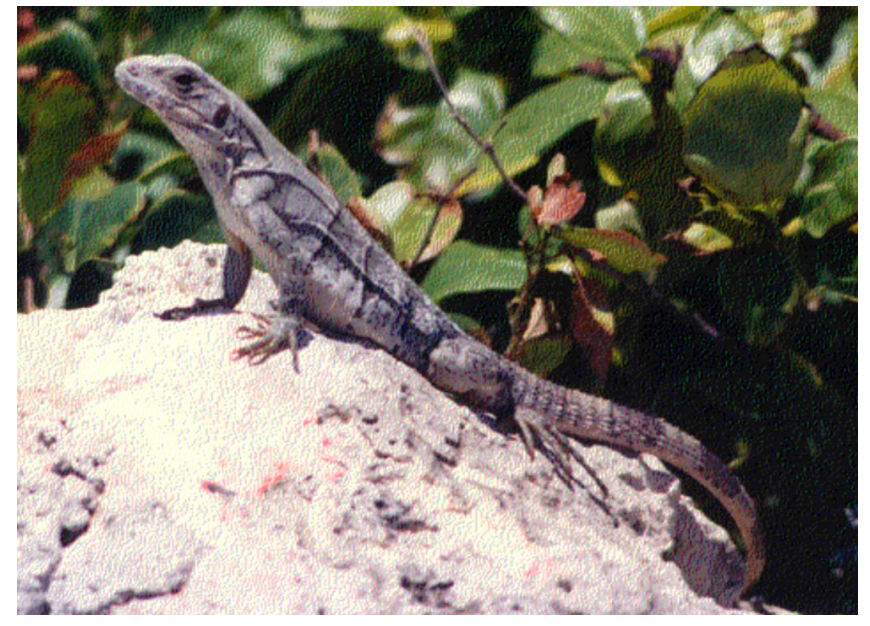

Figure 5. Female black spiny-tailed iguana (Ctenosaura similes). Credits: W. H. Kern, Jr., University of Florida, Ft. Lauderdale
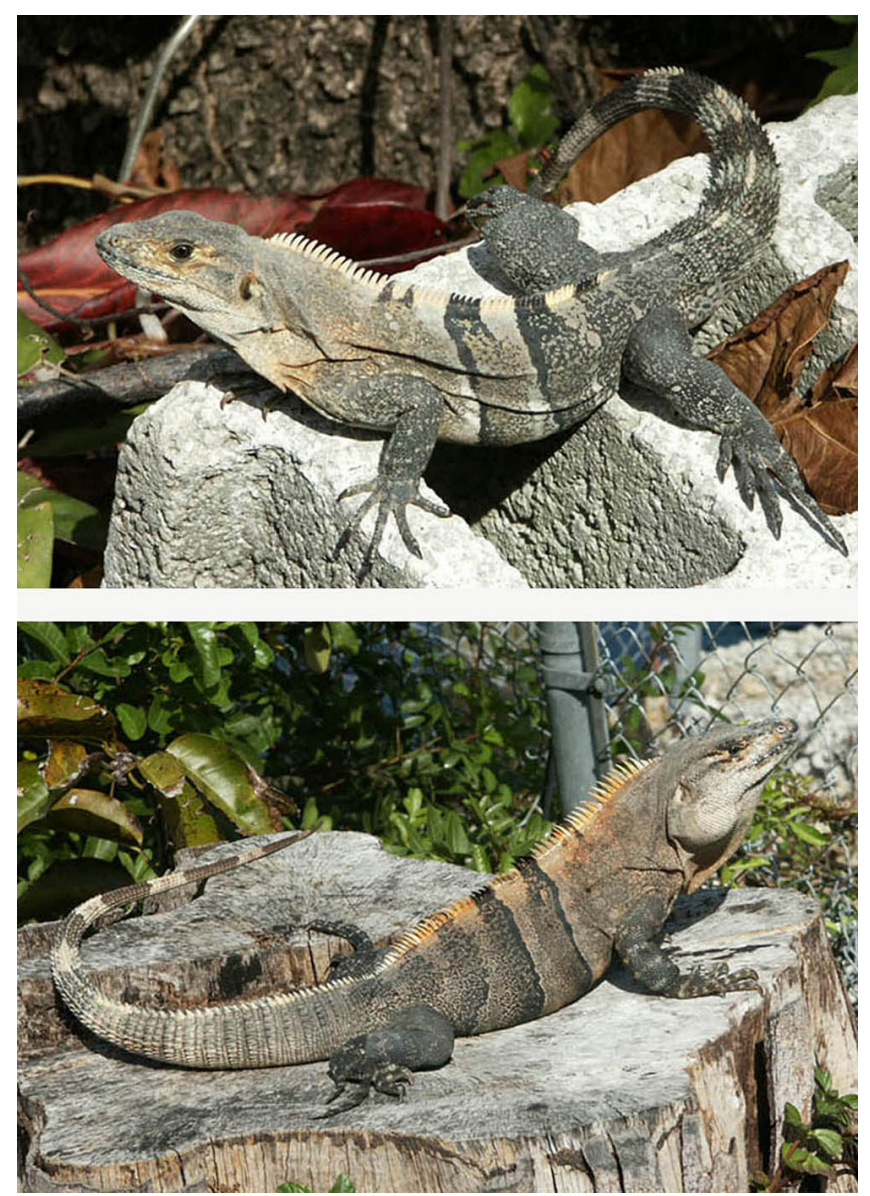

Figure 6. Adult female (top) and male (bottom) Mexican spiny-tailed iguana (Ctenosaura pectinata). Credits: Vinda B. Maharajh, University of Florida, Ft. Lauderdale REC

(spiny tailed iguanas). This habit of diving into the water to escape makes green iguanas very difficult to capture. Basilisks and anoles generally eat insects and 


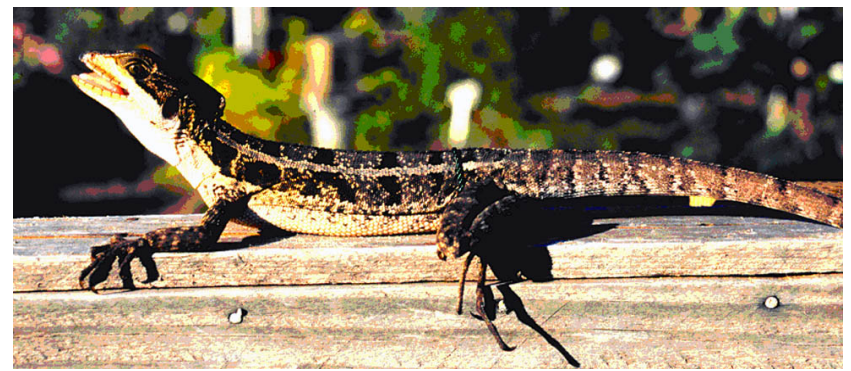

Figure 7. Female brown basilisk (Basiliscus vittatus). Males are larger, brighter, with a much larger crest on the back of the head. Credits: W. H. Kern, Jr., University of Florida, Ft. Lauderdale

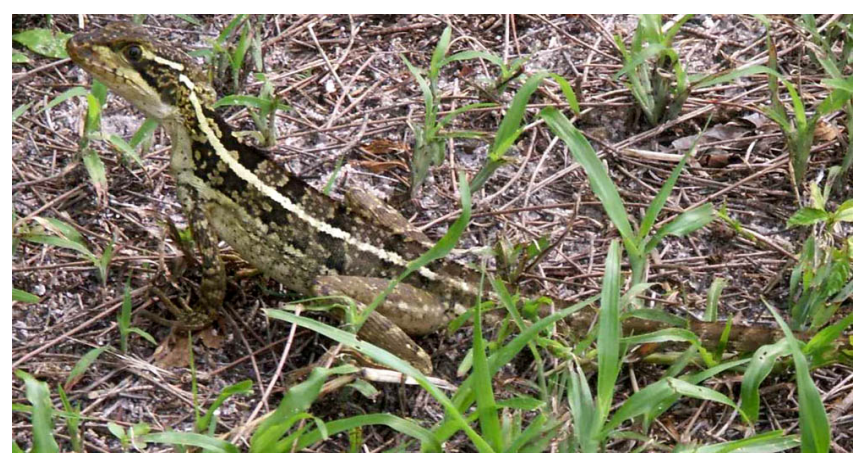

Figure 8. Juvenile brown basilisk (Basiliscus vittatus). Credits: W. H. Kern, Jr., University of Florida, Ft. Lauderdale

small vertebrate prey, but Knight anoles occasionally eat small fruits and flowers as well.

\section{Damage}

Damage caused by iguanas includes eating valuable landscape plants, shrubs, and trees, eating orchids and many other flowers, eating dooryard fruit like berries, figs, mangos, tomatoes, bananas, lychees, etc. Iguanas do not eat citrus. Burrows that they dig undermine sidewalks, seawalls, and foundations. Burrows of iguanas next to seawalls allow erosion and eventual collapse of those seawalls. Droppings of iguanas litter areas where they bask. This is unsightly, causes odor complaints, and is a possible source of salmonella bacteria, a common cause of food poisoning. Adult iguanas are large powerful animals that can bite, cause severe scratch wounds with their extremely sharp claws, and deliver a painful slap with their powerful tail. Iguanas normally avoid people but will defend themselves against pets and people that try to catch them or corner them.

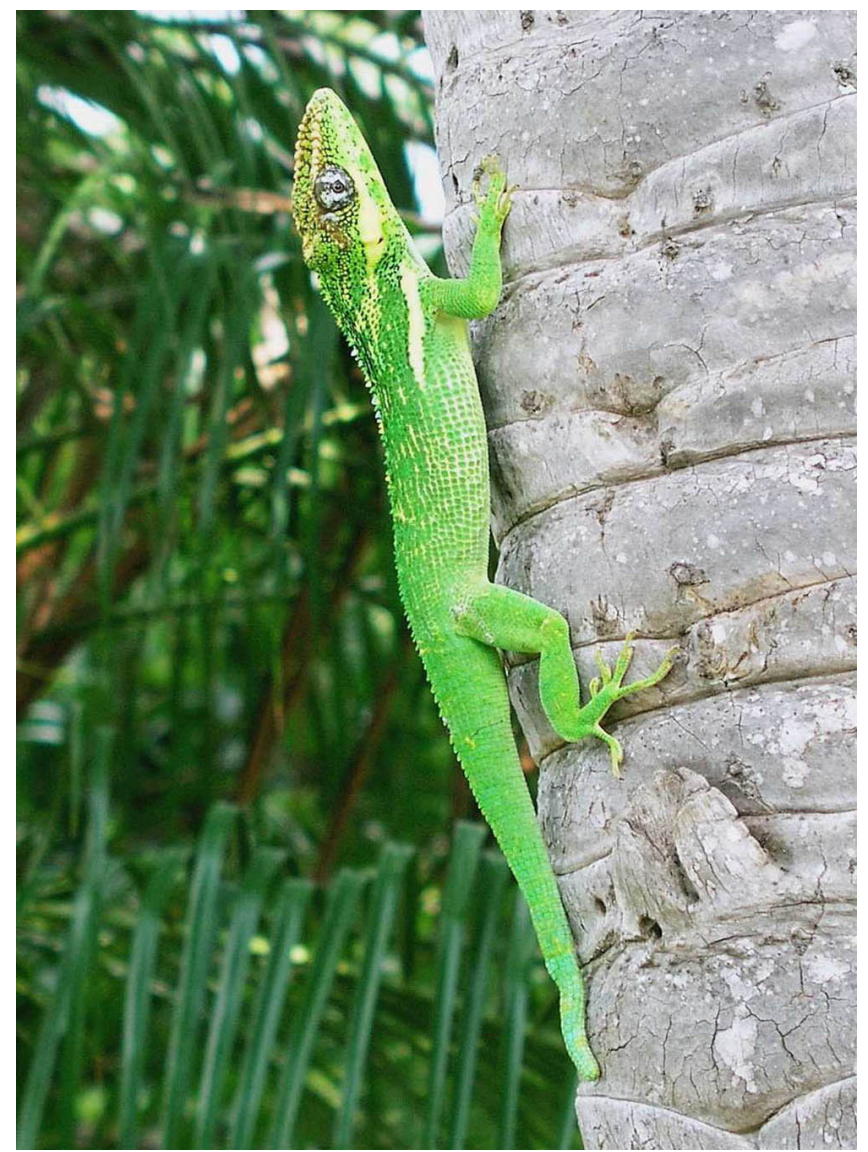

Figure 9. Adult knight anole (Anolis equestris). Credits: W. H. Kern, Jr., University of Florida, Ft. Lauderdale

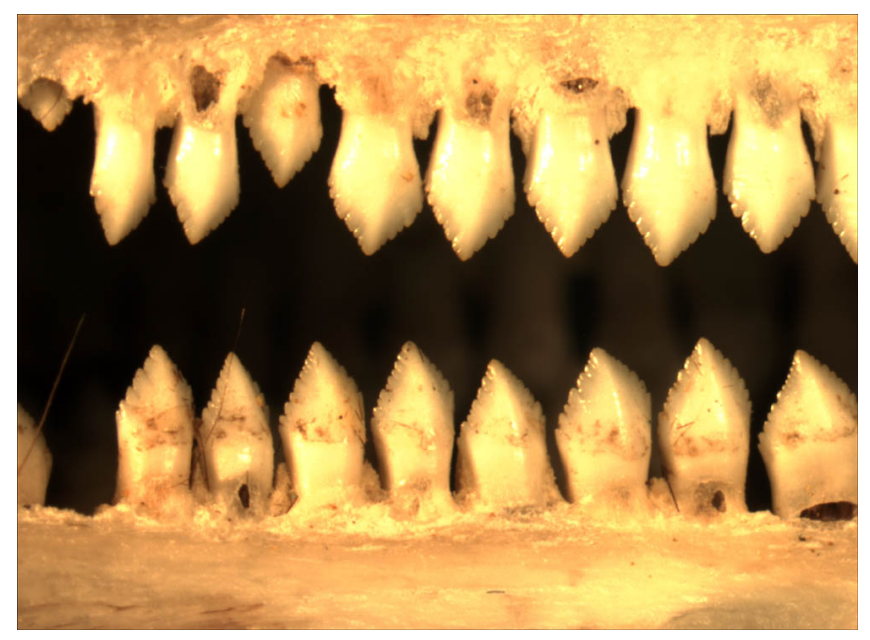

Figure 10. The teeth of a green iguana are designed to shear plant material, but can deliver a painful bite to people and pets. Credits: Karen Wheeler, University of Florida, Ft. Lauderdale 


\section{Control Options}

\section{Tolerance}

Many people enjoy sharing their living space with a few iguanas. Learn to appreciate these exotic creatures. Do not feed iguanas in your yard. This will attract more iguanas and can create problems for both you and your neighbors by creating unnatural concentrations. Do not become a nuisance to your neighbors by feeding iguanas. Pans of cut fruit will attract rats and raccoons as well as iguanas. Be a considerate neighbor and good environmental steward.

\section{Exclusion}

Protect valuable plants with cages or screen enclosures. There are currently no repellents registered for preventing feeding damage from iguanas.

\section{Habitat Modification}

Avoid planting species that are preferred food for iguanas (See Table 1).

Remove protective cover such as dense thickets and piles of landscape timbers or rocks. Sheet metal guards of trees, palms, and dock pilings will prevent them from climbing. Fill vacant burrows with concrete and sand during the day when the animals are likely to be away from the burrow. Electric fences on seawalls and docks may deter or stop iguanas from climbing up on to them. Persistent harassment will also encourage iguanas to move to safer pastures.

\section{Natural Enemies}

Raccoons, fish crows, vultures, feral pigs and other predators dig up iguana nests and eat the eggs. Raccoons, snakes, hawks, owls, egrets, herons, cats, and dogs kill the majority of hatchling and juvenile iguanas. After young iguanas reach about two feet in length, they have fewer natural enemies. Automobiles and people are the main cause of mortality of adult iguanas. Alligators may occasionally take adults in the water. In tropical America, large predators like ocelots, pumas, jaguars, anacondas, boa constrictors and people eat adult iguanas. Dogs occasionally catch iguanas in the open and can overtake them before they escape into the water or down their burrows to safety. Freezes keeps iguanas limited to the southern half of peninsular Florida.

\section{Capture and Removal}

Iguanas can be captured and removed from private property at any time without special permits. They are considered exotic unprotected wildlife. They may be caught by hand, noose pole, net, or traps. Only live traps and snares are legal in the State of Florida. Check with local authorities for any local ordinances that may limit control options. Babies can be caught by hand or with a thread or monofilament noose on a long bamboo pole. These can be sold or given to pet stores or exotic pet wholesalers. See Figure 3.

It is illegal to release iguanas in Florida (39-4.005 Florida Administrative Code). Iguanas are not native to Florida and so are not protected in Florida, except by anticruelty laws. Green iguanas are listed in the Convention on International Trade in Endangered Species II because of their economic importance and over-harvest for the international pet trade in their native range. In Florida, all captured iguanas must be kept in captivity as pets or captive breeding stock, or must be destroyed. Feral adult iguanas rarely make acceptable pets. They never tame sufficiently and are dangerous. Remember, they can deliver severe bites, scratches and blows with their muscular tails.

Trapping, either with live traps and snares, should be considered a last resort. Traditional live animal traps baited with grapes, pieces of ripe melon, papaya, or mango can be very effective, especially if the traps are prebaited for some time prior to setting the trap. Prebaiting simply means securing the door open and placing food in the trap so the animals get used to entering the trap for food. Once they are regularly entering the trap, release the door and set the trap normally. Florida law requires that animal traps be checked at least once every 24 hours. When trapping iguanas, or any animal, check the trap as often as possible. Iguanas will often get cuts and abrasions when trying to escape from traps. Covering the trap with a burlap bag or old blanket when setting it may reduce this behavior by making the animal feel less exposed or vulnerable. There are many other 
types of live traps that may catch iguanas, such as funnel entrance traps, etc.

Iguanas and many lizards hold their heads up, to better watch for predators, as they walk or run. This behavior makes them ideal candidates for snares. The 24-inch locking snares normally sold for trapping muskrats, mink, or rabbits are large enough for any iguana. Set snares at burrow entrances, holes under fences, along seawalls, or any place that iguanas regularly congregate or move. See Figure 12 on how to set a snare. Snares can kill by strangulation if they are set to do so or the animal struggles too long. Snares are not discriminating and can kill pets or wildlife if they are not carefully set and monitored. Snares set for iguanas should only be set during the day because iguanas are only active during the day, while cats, raccoons, and opossums are generally nocturnal.

During winter cold fronts, cold-stunned iguanas can sometimes be simply picked from branches or picked up off the ground after they fall from the trees. Using boats along canals and in the mangroves when the temperatures are in the $40 \mathrm{~s}^{\circ} \mathrm{F}$ has been very successful. This is a very effective method to reduce local iguana populations.

\section{Shooting}

Hunting with firearms is a very effective way to harvest iguanas for food in Central and South America. It is not legal or safe to discharge firearms (or pellet rifles) in suburban environments of South Florida where iguanas are commonly causing problems. Shooting is not recommended. Using a bow with tethered fishing arrows may be legal, but the humaneness is debatable. Check with local Florida Fish and Wildlife Conservation Commission officers or local law enforcement before using any projectile weapon. Slingshots with small pebbles or palm fruits may be a useful harassment tool, but should only be used under adult supervision and when you are very sure of your backstop. Rubber band guns have been used by scientist to collect small lizards and may stun juvenile iguanas long enough to capture them by hand.

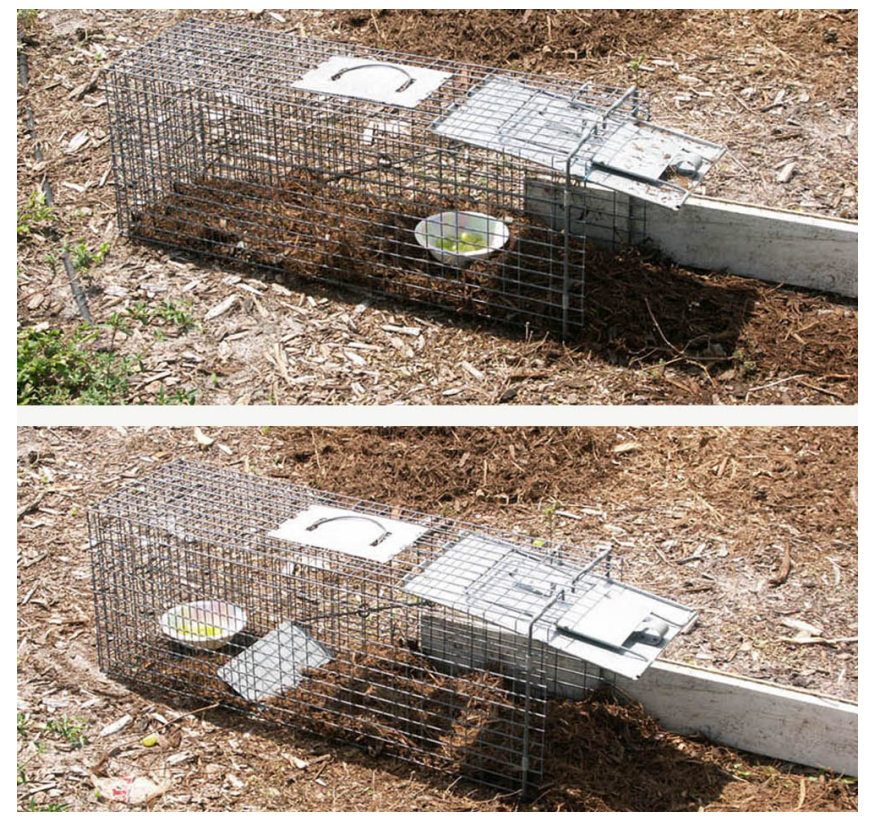

Figure 11. Live traps prebaited and wired open (top) and set (bottom) for iguanas. When you are prebaiting a trap, move the food farther into the cage each day the food is eaten. Cover the wire on the bottom with leaf litter, mulch, or soil so the lizard can't feel the wire under its feet. Use a drift fence (board) to help guide the animal in the trap. Credits: W. H. Kern, Jr., University of Florida, Ft. Lauderdale

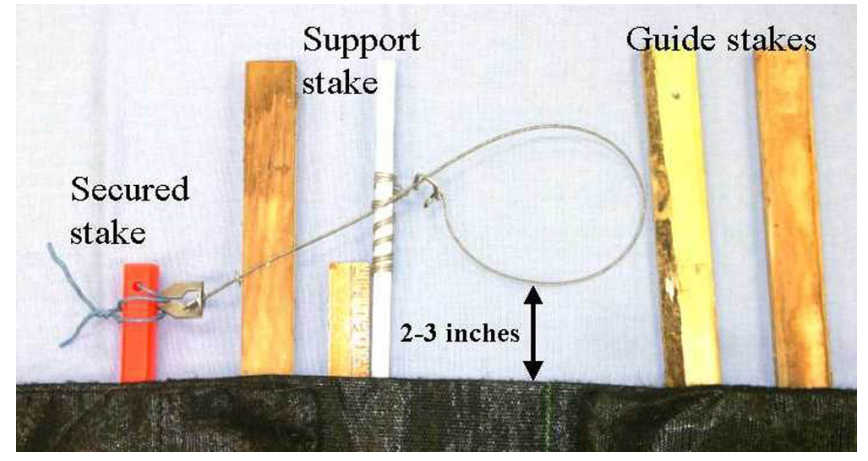

Figure 12. Self-locking snare set for iguanas. End of the snare is firmly attached to a stake or structure and the snare is wired into position with a support stake. The bottom of the snare loop should be 2 to 3 inches above the ground, depending on the size of the target animal. Credits: W. H. Kern, Jr., University of Florida, Ft. Lauderdale

\section{Eating}

The meat of adult iguanas and the eggs are eaten and considered a delicacy throughout their native range, especially during Easter week. As of 2004, the price of iguana meat was $\$ 14.00$ / pound in Maryland. Large adults, too dangerous to be kept as pets, may have value as meat in ethnic markets that cater to immigrants from Central and South America. 
However, make arrangements with the market manager before showing up with a sack of iguanas.

\section{Selected References}

Ashton, R. E., Jr. and P. S. Ashton. 1985.

Handbook of Reptiles and Amphibians of Florida,

Part II; Lizards, Turtles \& Crocodilians. Windward

Publishing Inc., Miami, FL. 191 pp.

Bartlett R. D. and P. P. Bartlett. 1999. A Field

Guide to Florida Reptiles and Amphibians. Gulf

Publishing Co., Houston, TX. 278 pp.

Stafford, P. J. and J. R. Meyer. 2000. A guide to the reptiles of Belize. Academic Press, San Diego, CA. $356 \mathrm{pp}$.

Wilson, L. D. and L. Porras. 1983. The Ecological Impact of Man on the South Florida Herpetofauna. Museum of Natural History, University of Kansas, Lawrence, KS, Special Publication No. 9. 89 pp. 
Table 1.

\begin{tabular}{||l|l||}
\hline \hline Preferred Iguana Food Plants & Iguana Resistant Plants \\
\hline Hibiscus, Including rosellia & Milkweed \\
Orchids & Pentas \\
Impatiens & Oleanders \\
Roses & Citrus \\
Nasturtiums & Crotons \\
Garden greens - Kale, broccoli, mustard, & Other toxic plants \\
\multicolumn{1}{|c||}{ collards, sorrel, beets, lettuces } & Tough, thick leaved plants \\
Squashes and melons & \\
Most fruits and flowers & \\
Most tender new growth & \\
Hong Kong Orchid Tree & \\
Purple Queen (Setcreasea sp.) & \\
\hline \hline
\end{tabular}

